\title{
Spíše Wikipedie než učebnice: Způsoby využívání otevřených vzdělávacích zdrojů studenty environmentálních oborů
}

\section{Eduard Petiška}

\section{Envigogika 13 (2) - Recenzované články/ Reviewed Papers}

Publikováno / Published 10. 12. 2018

DOI: $\underline{10.14712 / 18023061.569}$

\begin{abstract}
Abstrakt
Cílem našeho výzkumu bylo popsat některé současné výzkumy zabývající se způsoby využívání otevřených vzdělávacích zdrojů (OER) na úrovni vysokoškolského vzdělávání a odpovědět na výzkumnou otázku: "Jaké jsou způsoby využívání OER studentů environmentálních oborů v České republice?". Výzkum byl realizován v rámci environmentálních kurzů na českých vysokých školách, celkem bylo vyhodnoceno 233 dotazníků pomocí metody $\mathrm{t}$ testu a Chi-square testu. Většina studentů používá OER často nebo častěji než uzavřené zdroje jako např. tištěná skripta. Dostupnost, množství informací a snadná orientace patří mezi nejoceňovanější výhody při využívání OER. Můžeme proto konstatovat, že vzhledem $\mathrm{k}$ popularitě OER by měly také vzdělávací instituce zaměřit svoji pozornost na tento fenomén.
\end{abstract}

\section{Klíčová slova}

Otevřené vzdělávací zdroje; vysoké školství; environmentální obory

\begin{abstract}
The aim of the research is to describe current debates about OER usage on the higher education level, and answer the research question: "What are the ways of using the OER by students of environmental disciplines in the Czech Republic?" Research was realized in the context of environmental disciplines in the Czech Republic. The data was acquired through a survey questionnaire $(n=233)$. Two kinds of statistical tests were performed: 1$) t$-test and 2) Chi-square test. Most students use OER as often as or more often than classical materials. Wikipedia is the most used resource. Availability, amount of information and easy orientation are the most value benefits of OER usage. Because of the popularity of OER among students, educational institutions should focus their attention on OER.
\end{abstract}

\section{Keywords}

Open education resources; higher education; environmental disciplines 
Digitální doba má vliv na řadu aspektů našeho života včetně vzdělávání. Internet může přispět $\mathrm{k}$ demokratizaci vzdělávání (Acemoglu a kol., 2014). Trendy směřují k otevřenému sdílení vzdělávacích materiálů jako jsou kvalitní učebnice (např. openstax), online přednášky (fenomén $\mathrm{MOOC}$ ) či vědecké články (trend open access). Se vzrůstající popularitou vzdělávacích materiálů (Allen \& Seaman, 2016), které jsou volně k dispozici, se objevila i potřeba nového termínu a teoretického rámce pro jejich popis. Začíná se používat pojem Open Educational Resources (OER) (Wiley a kol., 2014), aby se zdůraznila skutečnost, že tyto materiály jsou $\mathrm{k}$ dispozici otevřeně všem (bez poplatků).

OER mají velký potenciál pro využití na všech úrovních vzdělávání, včetně vysokoškolského vzdělávání (HE) (Butcher, 2010). Mezi nejužívanější vymezení OER patří definice Hewlett Foundation: "(OER jsou) výukové, vzdělávací a výzkumné zdroje, které jsou ve veřejném vlastnictví, nebo byly vydány pod takovou licencí duševního vlastnictví, která umožňuje jejich volné použití a opětovné úpravy ostatními uživateli." (Hewlett Foundation, 2018). Uvádí se také, že tyto zdroje by měly splňovat tzv. "pravidlo 4 R": Reuse (možnost opětovného použití), Redistribute (možnost sdílení), Revise (možnost editace), Remix (možnost vytváření nových OER pomocí kombinace stávajících) (Hilton a kol., 2010). Významným mezníkem v etablování OER byla Kapská deklarace otevřeného vzdělávání, která klade důraz na podporu otevřeného př́stupu ke znalostem. $V$ České republice se o prosazování konceptu otevřené znalosti, vzdělávání a OER snaží Aliance pro otevřené vzdělávání. Studie, která diskutovala definice OER a využívání tohoto termínu $v$ českém prostředí, došla k závěru, že $\checkmark$ českém kontextu se tento termín používá zřídka (Kapitulčinová a kol., 2015). Definice OER se také různí a tento pojem se používá $v$ různých kontextech. $V$ rámci této studie pojmem OER myslíme zdroje, které jsou volně k dispozici na internetu k využívání pro každého (tedy ne univerzitní databáze, př́stupné jen studentům či e-zdroje, za jejichž využívání se musí platit).

„PY̌ístup k informacím a znalostem" je vymezen jako důležitá podmínka pro plnění cílů udržitelného rozvoje (ITU - International Telecommunication Union, 2015). Existence OER vede totiž ke zvyšování dostupnosti/kvality vzdělávání, což je důležité pro udržitelný rozvoj. OER pomáhá vyplnit mezery ve vzdělávacích materiálech pro vzdělávání pro udržitelný rozvoj (Roeder a kol., 2017) a zdá se být přínosem pro studium životního prostředí. Faktor "otevřenosti" má velký význam v oblasti životního prostředí, kde by měly být informace sdíleny, aby se zabránilo nejrůznějším rizikům. Princip otevřenosti v oblasti životního prostředí (ŽP) poprvé formulovala Aarhuská úmluva, která zaručuje všeobecné právo na přístup k informacím o životním prostředí. Zásada otevřenosti je zvláště relevantní pro environmentální studia, kde dochází ke komplexnímu propojení vědních oborů (Dlouhá a kol., 2015). Můžeme identifikovat tři hlavní důvody pro využívání OER v environmentálních disciplínách (Petiška, 2018):

- Snadnost aktualizace. Vzhledem ke značnému nárůstu zkoumání různých aspektů životního prostředí dochází také k rychlému zastarávání dřívějších poznatků. Je proto kladen požadavek na častou aktualizaci zdrojů. Obměna tištěných zdrojů je oproti elektronickým časově, materiálně i finančně náročná.

- Transdisciplinarita. Environmentální problémy jsou ze své podstaty transdisciplinární povahy, z tohoto důvodu je vhodné, aby materiály byly vytvářeny kolaborativně (bud' př́mo psány či recenzovány kolektivem odborníků). Digitální prostředí navíc poskytuje specifické výhody pro snazší orientaci $v$ různých tématech (formou odkazů, využívání volně dostupných materiálů atd.). 
- Přístupnost. Zpřístupňování informací různým skupinám aktérů je velkou výzvou právě v oblasti životního prostředí. Otevřené platformy jsou pro to ideálním nástrojem.

Používání OER také přináší řadu otázek a problémů. Byly identifikovány faktory, které představují hlavní překážky při jejich využívání a implementaci do školních kurikulí (Hylén, 2006): 1) Udržitelnost (tedy spolehlivost v průběhu času). Nestačí vytvořit OER, tyto zdroje musí být také pravidelně aktualizovány nejnovějšími poznatky. To platí zejména $v$ environmentálních disciplínách, kde se znalosti rychle vyvíjejí. 2) Duševní vlastnictví a autorská práva. Mnoho tvưrců a uživatelů OER nemá dostatečné zkušenosti s legislativou duševního vlastnictví a licencí. Pokud jsou tyto zdroje uveřejněny pod licencí, která neumožňuje jejich bezplatnou distribuci, není možné je používat jako OER. 3) Problém s kvalitou. OER mají různou kvalitu, často postrádají kritéria kvality a/nebo garanta kvality. Napríklad environmentální OER dostupné v českém jazyce se vyznačují různou kvalitou (Dlouhá a kol., 2015). 4) Interoperabilita (provázanost různých systémů). Základním principem OER je jejich volné využívání a modifikace. Každý systém OER by proto měl být interaktivní a umožňovat spolupráci pro propojení informací z různých odvětví, což je však často v rozporu s omezeními, která představuje duševní vlastnictví.

Je také nutné respektovat zásadu, že OER by měly být nejvíce používány aktivně (šírit informace, kopírovat a upravovat texty apod.) a proto často nejsou určeny $k$ použití pouze pro studijní účely. Může být problematické definovat nároky na komplexitu, kvalitu a formu daného (žánr) OER. Při jejich vytváření je proto vhodné pamatovat na cílovou skupinu, tedy zda vytvářený zdroj je spíše pro všechny (jako Wikipedie) či pro konkrétní uživatele, např. studenty určitého oboru vysokých škol (jako Wikiskripta, jež jsou určená medikům). Pro svůj dynamický rozvoj jsou OER námětem množství výzkumů zejm. v USA a Evropě (viz The Review Project, který mapuje tematické studie). Cílem tohoto příspěvku je popsat některé současné výzkumy zabývající se způsoby využívání otevřených vzdělávacích zdrojů (OER) na úrovni vysokoškolského vzdělávání a prezentovat výsledky našeho výzkumu.

\section{Způsoby využívání}

Jeden z prvních výzkumů zaměřených na problematiku využívání OER studenty byl proveden ve Velké Británii na Oxfordské univerzitě (Masterman a kol., 2011). Výsledky kvalitativní studie provedené na malém vzorku studentů poukazují na nízkou úroveň, co se týče povědomí o OER a principech duševního vlastnictví. Studenti upřednostňují on-line materiály a na druhé straně se zdráhají zveřejňovat vlastní práce volně na webu. Ve Velké Británii byly rovněž analyzovány způsoby využívání OER kvantitativní metodou na velkém souboru studentů ( $n=2807$ ) (Bone, McNichol, 2014). Výsledky ukázaly, že studenti mají pozitivní vztah k OER, využívají je z různých důvodů a očekávají, že tyto zdroje budou v budoucnu hrát větší roli. Závěry studie zdůrazňují potřebu lépe vysvětlit úlohu OER ve vzdělávání a potřebu praktické podpory při zkoumání a využívání těchto zdrojů.

Způsoby využívání a překážky při používání OER byly zkoumány ve studii na univerzitě Zhejiang v Číně (Hu a kol., 2015). Výsledky ukázaly, že více než tři čtvrtiny studentů mají zkušenosti $s$ používáním $O E R$, a to $s$ využitím materiálů z webových stránek univerzity, stejně jako z komerčních stránek. Ukázalo se také, že čím déle studenti studují, tím více se seznámí s OER. Jako hlavní důvod pro využívání OER byla zmiňována podpora vlastního studia, získávání informací, které přesahují znalosti dostupné $\mathrm{z}$ jiných zdrojů a př́stup $\mathrm{k}$ prezentacím čínských a zahraničních odborníků. Kolem jedné třetiny studentů uvedlo, že využívají OER jednou měsičně, přibližně čtvrtina studentů uvedla, že tyto zdroje využívají jednou týdně a jen velmi málo z nich využívalo OER častěji. Nejpopulárnější formát, který 
studenti zmiňovali, je video, následované texty, sylaby, online zprávami a diskuse. Mezi překážkami byly zmíněny jak individuální, tak obsahové faktory, stejně jako složitost prostředí OER a nedostatek institucionální podpory.

Způsoby využívání otevřených vzdělávacích zdrojů byly zkoumány také na univerzitě Lagos v Nigérii (Onaifo, 2016). Výsledky naznačují, že vnímání OER účastníky bylo obecně pozitivní, ukázalo se, že respondenti: 1) Využívají OER tím, že je používají jako doplňky $k$ vzdělávacím zdrojům, které byly formálně doporučeny jejich školami. 2) OER využívají $k$ usnadnění sdílení (výměny) akademických informací. 3) Měli užitek z všudyprítomné dostupnosti OER. 4) Využili také další možnosti, které OER poskytují pro výuku. 5) Měli prospěch z používání OER, protože zdroje jsou zdarma. Výsledky také poukázaly na nepříznivé faktory, kterým respondenti využívající OER, čelí: 1) Náklady spojené s využiváním těchto zdrojů (poplatek za internetové připojení). 2) Narušení př́ístupu k OER kvůli okolnostem jako jsou špatné internetové služby a přerušovaná elektřina; 3) Nedostatečné dovednosti pro přístup k OER.

Další studie o povědomí, nabídce a přijetí OER a MOOC byla provedena $v$ Japonsku (Shigeta a kol., 2017). Výsledky ukazují, že OER se využívají ke zlepšení učebního prostředí pro studenty, zatímco MOOC mají za cíl podporovat celoživotní učení. Ve srovnání se studií provedenou $v$ roce 2013 v Japonsku tyto výsledky ukázaly, že povědomí o OER se mírně zvýšilo a počet nabízených MOOC se během dvou let zvýšil výrazně. Hilton (2016) provedl přehled současného výzkumu o využití OER ve vysokoškolském vzdělávání. Analyzoval šestnáct studií, které zkoumaly dopad OER na studijní výsledky a na vnímání OER studenty a učiteli. Hodnocení ukázalo, že studenti, kteří používají OER, dosahují stejných výsledků při učení jako studenti, kteří studují z klasických učebnic; navíc studenti, kteří používají OER, ušetří značné finanční prostředky. Není proto překvapující, že tito respondenti (studenti a zástupci univerzit, kteří byli obeznámeni s OER) vnímali OER pozitivně. Hilton však konstatuje, že tyto studie nemusí být dostatečně průkazné. Některé z nich vykazují nedostatky jako je nedostatečný počet respondentů, slabá metodika a problematický vzorek (respondenti měli již před zahájením výzkumu pozitivní vztah k OER). Je zřejmé, že ačkoli je vnímání OER zkoumáno, stav znalostí je stále nedostatečný a proto je potřeba dalšího zkoumání.

V České republice byl realizován výzkum, který se zaměřoval na využívání konkrétních OER, jež mohou sloužit pro studium environmentální problematiky (Petiška, 2018). U jednotlivých OER byla zkoumána frekvence využívání, účely využívání (tedy, zda je využívání spíše jako hlavní zdroj, doplněk atd.) a subjektivní hodnocení kvality. Ukázalo se, že většina studentů využívá OER často, zejm. Wikipedii - a to jak její českou, tak anglickou verzi. Řada z nich má zkušenosti také s dalšími OER. Zdroje využívají zejména jako doplněk a sekundární zdroj (tedy ne hlavní zdroj), případně rozcestník $k$ dalším zdrojům či k př́pravě na zkoušky nebo psaní atestačních prací. Jako kvalitní zdroj hodnotí zejména Wikipedii. Většina studentů byla zároveň schopna určit alespoň některá kritéria, podle nichž posuzují kvalitu zdroje. Vyhodnocení a diskuze dalších dat z realizovaného výzkumu, která se zaměřují na konkrétní specifika využívání je předmětem této studie.

\section{Výzkumná metoda}

Ve výzkumu jsme se soustředili na charakteristiky využívání OER ke studijním účelům. Naším cílem bylo odpovědět na výzkumnou otázku: "Jaké jsou způsoby využívání OER studentů environmentálních oborů v České republice?" Kvantitativní výzkum proběhl formou dotazníkového šetření. Studentům byly rozdány tištěné dotazníky. Výzkum zahrnoval studenty environmentálních kurzů na pěti českých univerzitách; průzkum byl dokončen $v$ akademickém roce 2016/2017. 
Dotazník byl vytvořen na základě již realizovaného výzkumu, který mapoval způsoby využívání OER studenty na univerzitě v Zhejiang (Hu a kol., 2015); tamní výzkumníci zkoumali studentské využívání OER (zdroje, které využívají, jak se o nich dozvídají, účel využívání atd.), tak specifické bariéry, které jim při jejich využívání brání (např. prostředí, obsah atd.). Některé otázky byly navrženy ve vztahu $\mathrm{k}$ výsledkům předešlého výzkumu zaměřeného na environmentální OER, $v$ němž byly nastíněny kvalitativní aspekty OER $v$ oblasti životního prostředí (Dlouhá a kol., 2015). V předešlém výzkumu jsme zkoumali specifika využití jednotlivých OER jako využívání konkrétních zdrojů, účely, frekvence a hodnocení kvality (Petiška, 2018). $V$ této studii se zaměřujeme na obecné způsoby využívání $O E R$, tedy již nediskutujeme konkrétní OER ale trendy $v$ této oblasti jako je míra využívání ve srovnání $s$ uzavřenými zdroji jako jsou tištěná skripta, míra využivání konkrétních médií (webů, videí) či způsoby informování o OER. Po vyplnění dotazníků studenty byly odpovědi nakódovány a data přepsána do tabulky v programu Excel. Celkově se výzkumu zúčastnilo 233 respondentů (tabulka č. 1). Účast byla anonymní a dobrovolná.

Tabulka 1. Vzorek respondentů

\begin{tabular}{|l|r|r|}
\hline & \multicolumn{1}{|l|}{ Počet } & \multicolumn{1}{l|}{ Procenta } \\
\hline Muži & 91 & $39 \%$ \\
\hline Ženy & 142 & $61 \%$ \\
\hline Bakalářský obor & 110 & $48 \%$ \\
\hline Magisterský obor & 120 & $52 \%$ \\
\hline Jihočeská u. & 89 & $38 \%$ \\
\hline Karlova u. & 30 & $13 \%$ \\
\hline Masarykova u. & 31 & $13 \%$ \\
\hline Ostravská u. & 50 & $21 \%$ \\
\hline Palackého u. & 33 & $14 \%$ \\
\hline
\end{tabular}

Data byla analyzována pomocí statistických testů (pro zjištění statistické významnosti). Byly provedeny dva druhy statistických testů: 1) t-test a 2) Chi-square test. T-test byl použit, když byla analyzována číselná (škála) proměnná na základě kategorické proměnné (stupeň studia, pohlaví). Interpretace t-testu je následující: Je-li hodnota $\mathrm{p}$ testu nižší než 0,05 (tj. úroveň významnosti 5\%), pak existuje statisticky významný rozdíl mezi oběma skupinami (pohlaví a stupeň studia). Je-li hodnota $p$ vyšší než 0,05 , neexistují žádné statisticky signifikantní rozdíly, tedy rozdíl mezi oběma skupinami není statisticky významný. Test Chi-square byl použit, když byla kategorická proměnná analyzována na základě dalších kategorických proměnných. Test Chi-square je založen na tabulce možností (frekvence). Výsledky testu Chi-square jsou uvedeny v hodnotě $p$. Je-li hodnota $p$ testu nižší než 0,05 (tj. $5 \%$ významová úroveň), pak existuje statisticky významný vztah mezi dvěma kategorickými proměnnými. Pokud je vyšší, neexistuje statisticky významný vztah mezi těmito dvěma proměnnými. Tyto testy byly zvoleny, protože se jedná o standardní testy používané 
v dotazníkových šetřeních. Typ proměnné (kategorický, číselný) byl hlavní důvod, proč byl použit t-test nebo Chi-square test.

\section{Otevřené vzdělávací zdroje v environmentálních oborech}

Zdroje, jejichž využívání jsme zkoumali, byly vybrány na základě předchozího výzkumu (Dlouhá a kol., 2015) a následného předběžného výzkumu, který byl proveden mezi studenty, abychom zjistili, jaké zdroje skutečně využívají pro studium (tabulka 2 ).

Tabulka 2. Popis zdrojů, které nejčastěji využívají studenti (dle Dlouhá a kol, 2015).

Hodnoty kódů (ANO, NE, 0) představují jejich zjednodušený kvalitativní popis: ANO znamená, že kritérium bylo víceméně splněno, NE znamená naopak, že nebylo. Hodnota 0 byla použita, když nebylo možné přiřadit předchozí dvě "hodnoty" z různých důvodů. Položky v levém sloupci označují kritéria kvality.

\begin{tabular}{|c|c|c|c|c|}
\hline Název zdroje & $\begin{array}{l}\text { Environmenta- } \\
\text { listika }\end{array}$ & Enviwiki & Wikipedie & primat.cz \\
\hline copyright & ANO & ANO & ANO & ANO \\
\hline autorství & $\mathrm{NE}$ & ANO & ANO & 0 \\
\hline $\begin{array}{l}\text { datum publi- } \\
\text { kace }\end{array}$ & NE & ANO & ANO & ANO \\
\hline rádné citace & NE & 0 & ANO & 0 \\
\hline recenze & NE & 0 & ANO & NE \\
\hline $\begin{array}{l}\text { vyznačení kva- } \\
\text { lity }\end{array}$ & NE & 0 & 0 & NE \\
\hline $\begin{array}{l}\text { korektní po- } \\
\text { stupy }\end{array}$ & 0 & 0 & 0 & NE \\
\hline $\begin{array}{l}\text { „nabídka“ pro } \\
\text { VŠ výuku a roz- } \\
\text { víjené kompe- } \\
\text { tence z hlediska } \\
\text { EV a VUR }\end{array}$ & $\begin{array}{l}\text { Všechny pilíre } \\
\text { udržitelnosti v } \\
\text { globálním i lo- } \\
\text { kálním pohledu } \\
\text { - stručnost, pře- } \\
\text { hlednost, utří- } \\
\text { děná témata }\end{array}$ & $\begin{array}{l}\text { Multidiscipli- } \\
\text { nární povaha } \\
\text { textů umožňuje } \\
\text { skloubit po- } \\
\text { znatky z růz- } \\
\text { ných oblastí ŽP } \\
\text { a UR a propojit } \\
\text { aktéry a znalosti } \\
\text { (používání hy- } \\
\text { perlinků, kate- } \\
\text { gorie, atd). }\end{array}$ & $\begin{array}{l}\text { Mezioborové } \\
\text { propojení témat, } \\
\text { zdůraznění sou- } \\
\text { vislostí, mož- } \\
\text { nost propagace } \\
\text { témat (odkazy z } \\
\text { jiných stránek) }\end{array}$ & $\begin{array}{l}\text { Materiály nele- } \\
\text { gální (otázky ke } \\
\text { zkoušce atd.), } \\
\text { různá kvalita, } \\
\text { komerční cíl }\end{array}$ \\
\hline
\end{tabular}




\section{Výsledky a diskuze}

V níže uvedených grafech jsou uvedeny odpovědi týkající se způsobů využívání v dotazníku (Přiloha 1 , otázky č. 4,6,7,8,9).

Graf 1. Odpovědi na otázku, která zkoumá jaké OER studenti využívají ke studiu životního prostředí.

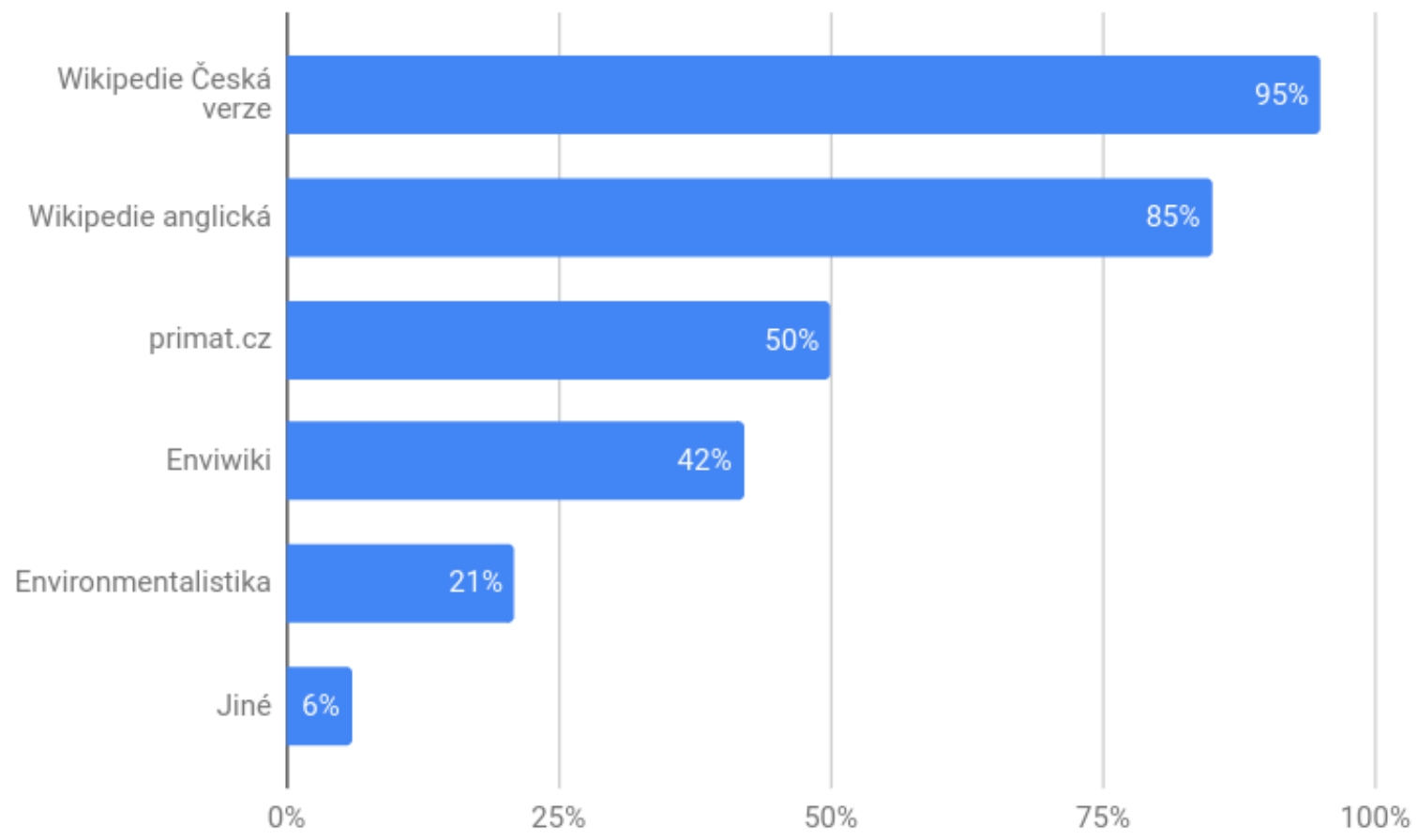

Z grafu 1 je patrné, že studenti většinou používají Wikipedii, a to jak českou, tak anglickou verzi. Jiné zdroje používají méně často. Mají také zkušenosti s primat.cz, což je internetový zdroj, který často obsahuje materiály, s jejichž používáním mohou vyvstat etické problémy (např. otázky ke zkouškám atd). Př́stup k tomuto zdroji je omezen (nezbytné je přihlášení). Studenti také využívají Enviwiki, specializovanou internetovou encyklopedii fungující na bázi Mediawiki softwaru, kterou provozuje Centrum pro otázky životní prostředí Univerzity Karlovy. Zdroj Environmentalistika, webový portál provozovaný Masarykovou univerzitou, využívají někteří studenti nehledě na to, že datum poslední aktualizace je 2002, což znamená, že i zastaralý zdroj je pro studenty stále zajímavý. 
Graf 2. Odpovědi na otázku: „Využíváš OER při studiu ŽP více či méně než uzavřené zdroje (např. tištěná skripta)?"

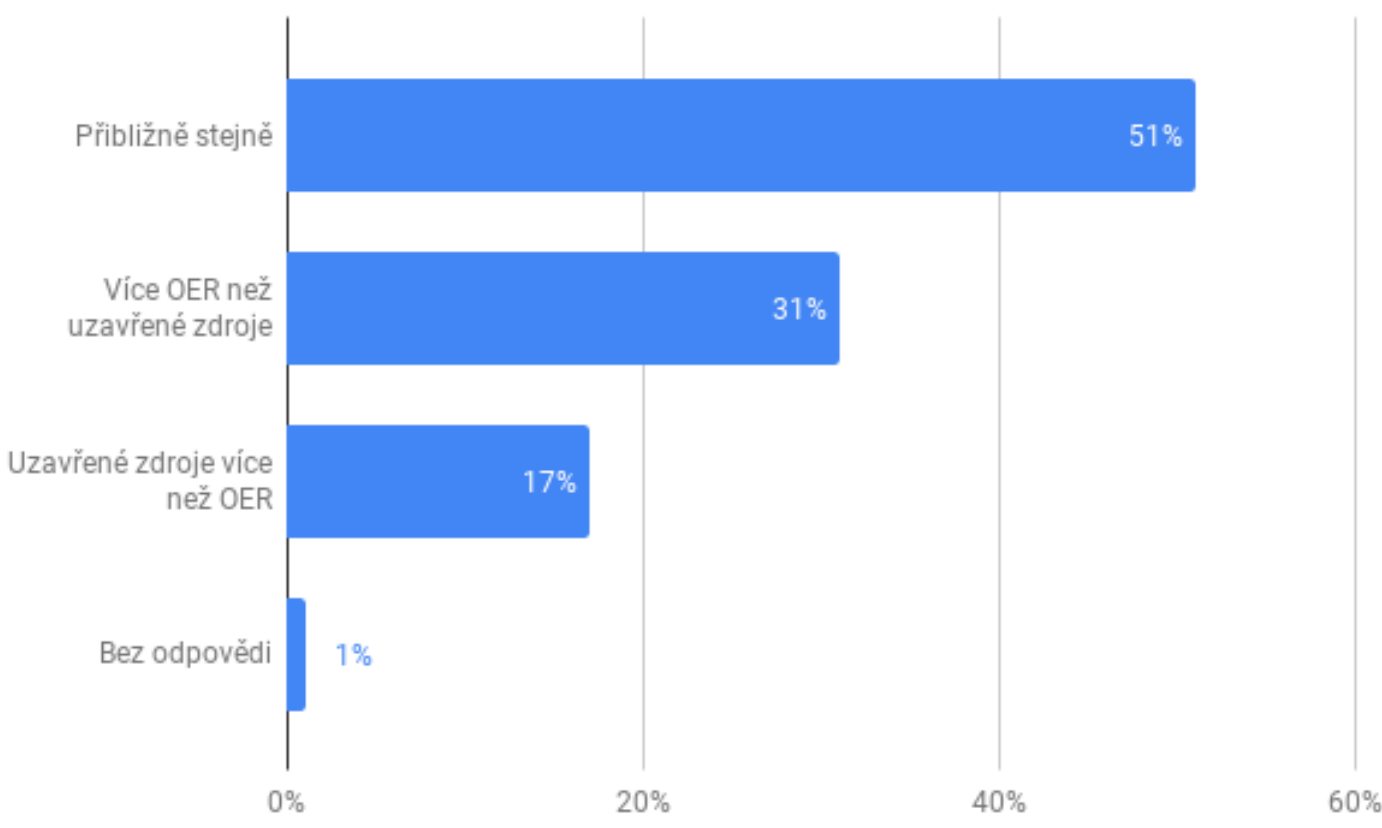

Více než polovina studentů uvedla (Graf 2), že používají OER stejně často jako uzavřené zdroje jako např. tištěné materiály a třetina z nich dokonce častěji; pouze $17 \%$ studentů používá více uzavřené zdroje. To znamená, že většinu informací potřebných k pochopení environmentálních problémů na relativně odborné úrovni považují studenti za dostupnou na internetu. Otázka typu nebo žánru těchto zdrojů je řešena v následující otázce. 
Graf 3. Odpovědi na otázku: „Ke studiu ŽP ze zdrojů OER nejčastěji využíváš (můžeš zakroužkovat více odpovědí)."

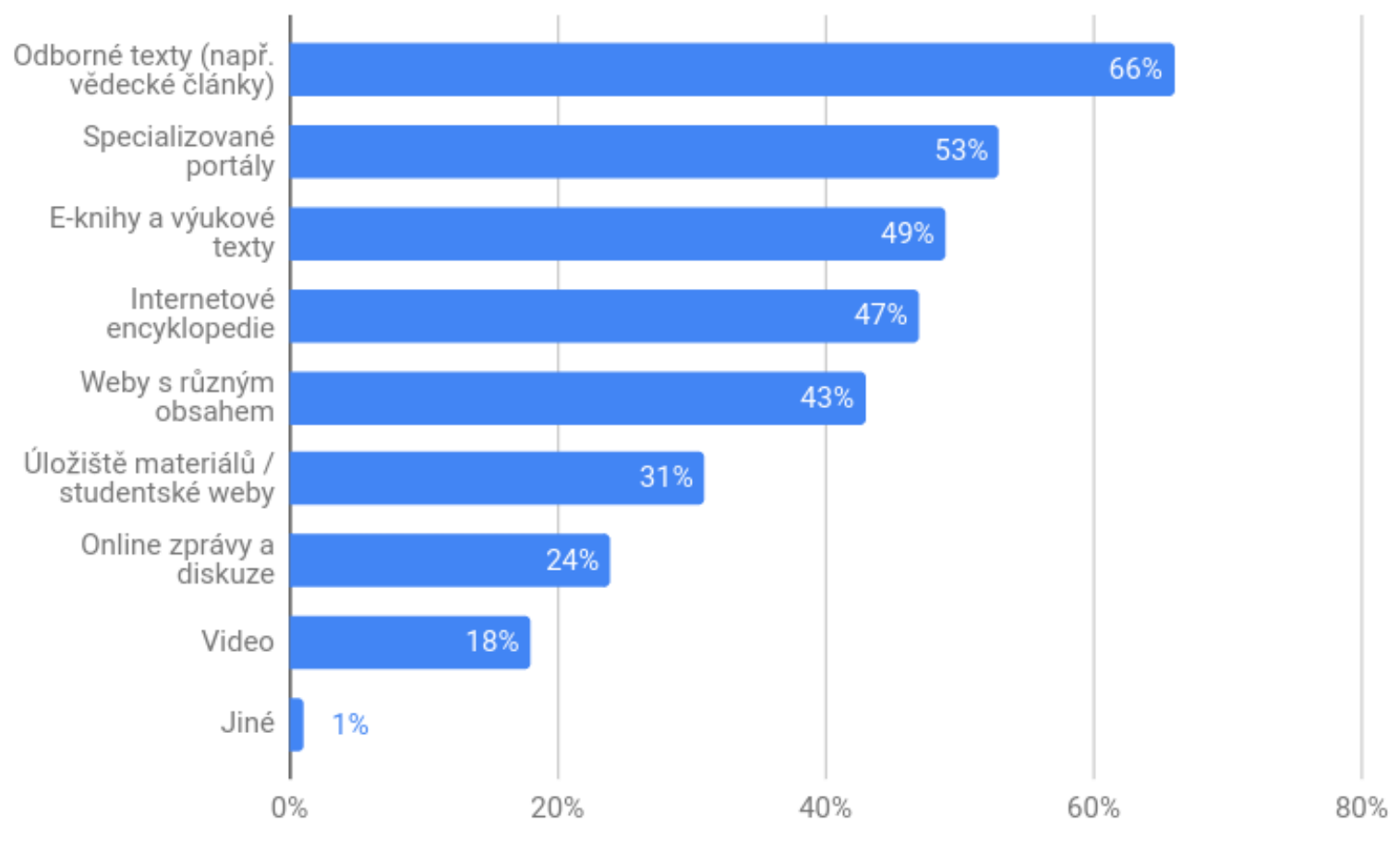

Z grafu 3 je patrné, že studenti většinou používají odborné portály a texty. Využívají také internetové encyklopedie, e-knihy a další vzdělávací zdroje. Video je nejméně využívaným zdrojem, což je překvapující vzhledem k popularitě YouTube a dalších platforem mezi mladými lidmi. Můžeme tedy spekulovat, že pokud studenti sledují videa, je to spíše pro zábavu než pro vzdělávání. 
Graf 4. Odpovědi na otázku: „Jak se dozvídáš o OER s problematikou ŽP? (můžeš zakroužkovat více odpovědí)."

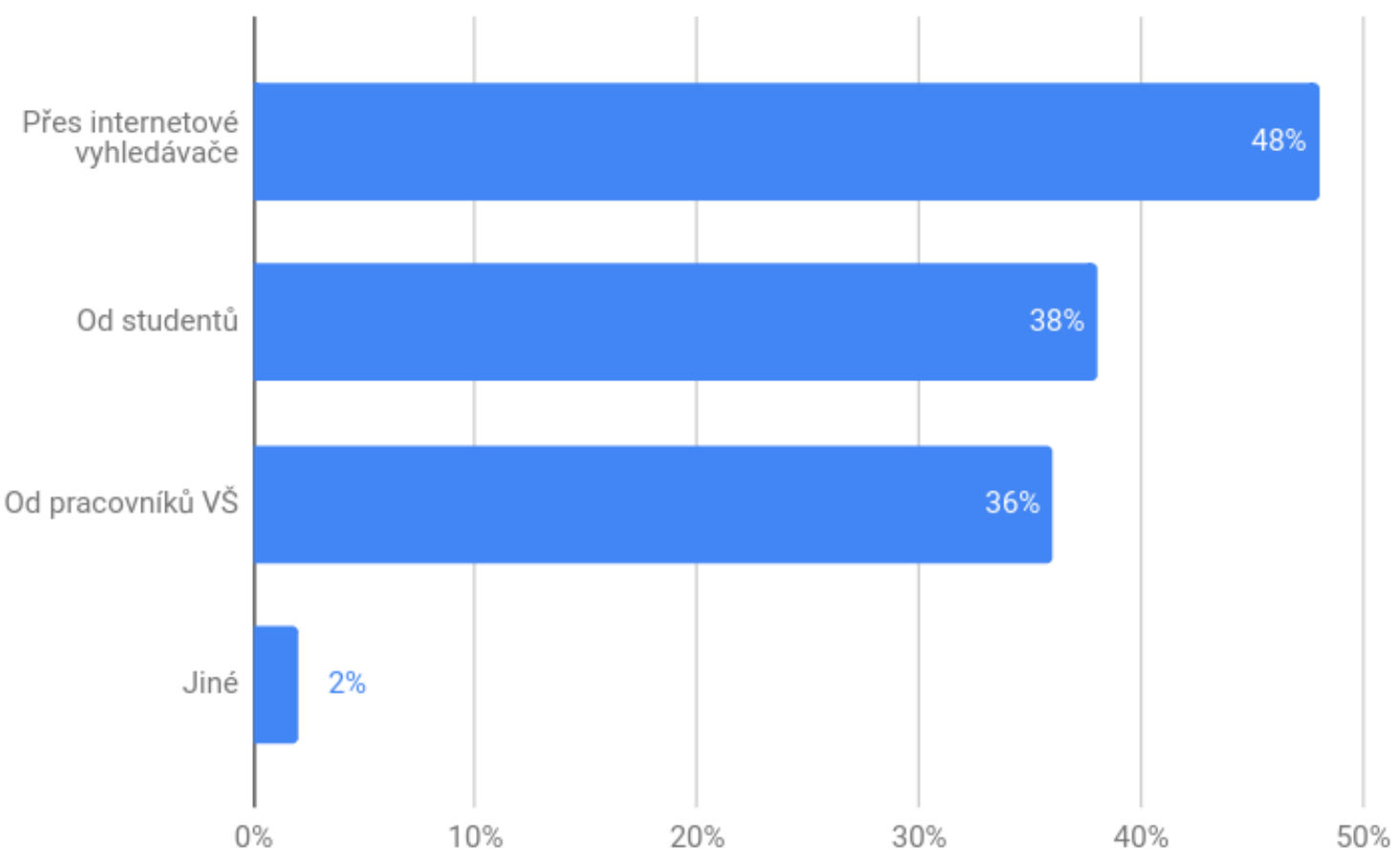

Graf 4 ukazuje, že se studenti o OER dozvídají nejčastěji díky internetovým vyhledávačům, od ostatních studentů a také od pracovníků VŠ. Zkoumání způsobů využívání OER z pohledu učitele by tedy mohlo představovat také zajímavý př́spěvek do debaty o OER. 
Graf 5. Odpovědi na otázku: "Co na OER, jež používáš ke studiu ŽP, oceňuješ nejvíce? (můžeš zakroužkovat více odpovědí)."

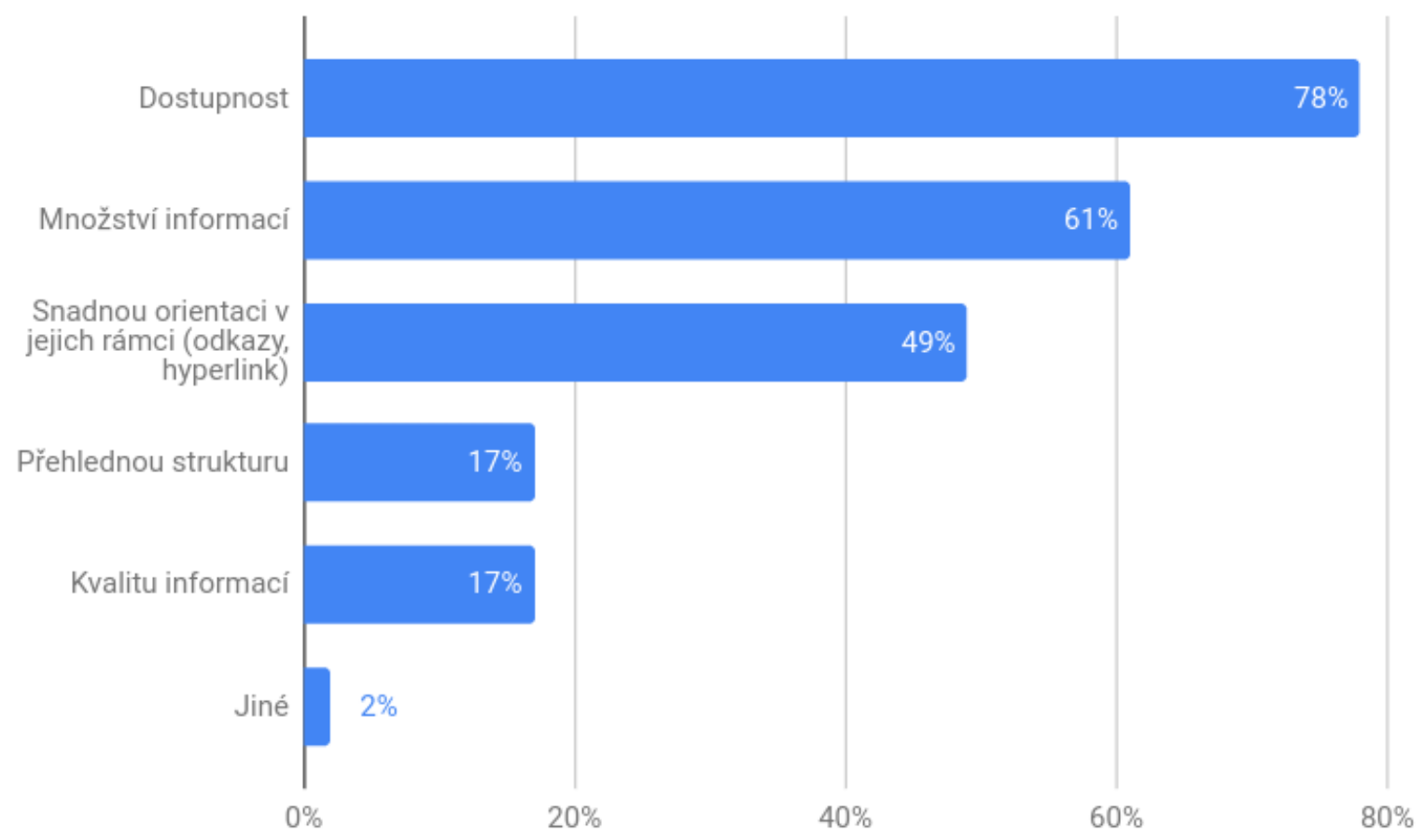

Graf 5 ukazuje, že studenti nejvíce oceňují dostupnost zdroje (78\%), množství informací $(61 \%)$ a snadnou orientaci v OER (49\%). Přehledná struktura zdroje a kvalita informací jsou naopak oceněny méně $(17 \%)$.

Nejdůležitější zjištění v našem výzkumu poukazuje na velký zájem studentů o využívání OER - více než 80 \% respondentů používá spíše OER než uzavřené zdroje jako např. tištěná skripta nebo OER stejně často. Pouze $17 \%$ respondentů používá spíše uzavřené zdroje. Rostoucí zájem o využívání OER potvrzují učitelé v USA (TES Global, 2016). Celková přiměřenost zdroje pro specifické vzdělávací potřeby $v$ kontextu vysokoškolského vzdělávání by mohla být zajištěna prostřednictvím zapojení studentů do tvorby jejich obsahu (pod dohledem učitelů) (viz výzkum zaměřený na roli studentů v podpoře sociální inkluze Hodgkinson-Williams \& Paskevicius, 2012). Postoj studentů k aktivnímu rozvoji OER a přispívání $k$ tvorbě jeho obsahu nebyl $v$ našem výzkumu zkoumán a může být námětem pro další výzkum.

Můžeme se domnívat, že čeští studenti a učitelé pravděpodobně používají OER spiše intuitivně bez důkladného povědomí o jejich možnostech a omezeních. Další výzkumy a zvyšování povědomí $v$ této oblasti by mohlo podpořit budování kapacit, aby byly $\mathrm{k}$ dispozici vhodné, aktuální a snadno dostupné zdroje dobré kvality, které by byly využity v souladu se specifickými potřebami studijního oboru a následně podpořit i procesy aktivního učení. Vzhledem k tomu, že studenti po celém světě (Bone, McNichol, 2014; Hu a kol., 2015) mají zájem o využívání OER, bude pravděpodobně nadále růst význam těchto zdrojů.

Motivace $k$ tvorbě OER může být v ČR podceňována kvůli nedostatku finančních pobídek: investice studentů do vysokoškolského studia (které je poskytováno zdarma) je nízká, 
takže i když s OER Ize dosáhnout podobného výsledku učení jako s klasickými zdroji (Hilton, 2016), finanční výhody jsou méně důležitým faktorem než v USA. Ukazuje se ale, že produkce učebnic začíná $v$ České republice klesat, můžeme proto spekulovat, zda jedním z důvodů není právě obliba OER (důvodem proč se nepíśi nové učebnice může být také to, že se za učebnice nezapočítají body v Rejstříku informací o výsledcích (RIV).

Vzhledem k tomu, že byl výzkum deskriptivní, zkoumali jsme pouze studentské vnímání. Zajímavé by však bylo zkoumat skutečné chování studentů při jejich online studiu. To by se dalo provést např́klad sledováním historie jejich prohlížeče při vyhledávání. Takový výzkum by byl technicky i časově náročný, jeho výsledky by nám ale mohly říci, zda studenti využívají zdroje skutečně tak, jak uvádí. $Z$ výsledků našeho výzkumu je totiž patrné, že ačkoliv studenti uvádí, že využívají zdroje na bázi Mediawiki softwaru (Wikipedie a Enviwiki), v další otázce, kde se jich ptáme na konkrétní typ zdrojů, patří mezi nejčetnější odpovědi kategorie "odborné texty" a "specializované portály". Vzhledem k tomu, že nepředpokládáme, že by studenti Wikipedii pokládali za tento typy zdrojů, můžeme se domnívat, že využívají ještě jiné typy, které neuvedli ( $i$ když $k$ tomu měli v dotazníku možnost). Může to být tím, že jména dalších zdrojů, které využívají neznají a používají je jednorázově, podle toho, kam je Wikipedie zavede, používají ji totiž hlavně jako rozcestník (Petiška, 2018).

Poskytnutí kvalitních zdrojů formou otevřeného přístupu (open access) může pomoci překonat různé (obvykle disciplinární) překážky, podporovat tak problémově orientovanou interdisciplinární komunikaci mezi všemi zainteresovanými subjekty (Dlouhá a kol., 2015) a nabízet aktuální informace o vzdělávání pro udržitelný rozvoj (Roeder a kol., 2017). Široce př́stupné OER, kde jsou prezentovány zevrubné informace o problematice životního prostředí, mohou posloužit i široké veřejnosti a prohloubit obecné znalosti o těchto tématech.

\section{Závěry}

Rozvoj internetu významně ovlivnil přenos znalostí. Jednou z nejdůležitějších inovací, které digitální éra přinesla, je fenomén otevřených vzdělávacích zdrojů. Tyto zdroje umožňují volně vytvářet, používat, sdílet a distribuovat vzdělávací materiály jak na místní, tak i na celosvětové úrovni. Začínají být využívané více než tradiční učební materiály. To platí zejména pro Wikipedii, která je pro většinu studentů nejrozšířenějším zdrojem - a to navzdory značné kontroverzi, kterou vzbuzuje $v$ akademickém prostředí. Využívání OER je trend, který $v$ budoucnosti pravděpodobně ještě akceleruje.

Vzdělávací instituce by proto měly začít problematiku OER reflektovat, věnovat pozornost schopnostem a kompetencím studentů pracovat $s$ těmito zdroji a obecně kultivovat tuto rychle se rozvíjející oblast. Důležité je zaměřit pozornost na získání zpětné vazby o využívání OER, výhodách a rizicích s tím spojenými. A na základě toho učinit konkrétní kroky vedoucí k využívání kvalitních OER. Bez toho budou studenti pravděpodobně používat OER stejně, ale s rizikem osvojení si neetické praxe (např. nepochopení základů citační praxe, což může vést $k$ plagiarismu) a návyku na využívání nekvalitních zdrojů (zdroji kde není vyznačen garant kvality, popř. tvrzení nejsou řádně ozdrojovaná).

Pro kultivaci internetového prostředí a vytváření kvalitních OER navrhujeme následující doporučení:

1. Vytvořit metodický materiál, který by kličcoým aktérům (tedy zejm. vysokoškolským pedagogům a dalším zodpovědným pracovníkům) poskytl jak obecný úvod do problematiky OER a jejího významu pro VŠ vzdělávání, tak zejména konkrétní rady a 
kroky, které je vhodné podniknout při vytváření a impelementaci OER do studijních kurikulí.

2. Inspirovat stávajícími platformami, zdroji a materiály při vytváření OER. Není často potřeba vytvářet vlastní systémy, u nichž bývá problém zajistit udržitelnost (např. z finančních a personálních důvodů). Namísto toho je možné využít již existující řešení kromě Wikipedie např. Wikisource a Commons (úložiště materiálů) či Wikibooks (portál pro tvorbu knih a učebnic). Při tvorbě obsahu je také možné využít to co je pod otevřenou licencí (nejrozšířenější jsou Creative commons) kromě výše zmíněného je možné při vytváření obsahu OER využít např. otevřené učebnice OpenStax a řadu dalších.

Problematika OER nabízí také mnohé další výzvy a př́ležitosti k výzkumům, např. jak podotkl jeden z recenzentů tohoto článku ve svém komentáŕi: „Na provedený výzkum a získané závěry Ize navázat dalším tématem, které je pro rozvoj OER ještě dưležitější než uživání otevřených vzdělávacích zdrojů studenty. A tím je vztah vysokoškolských pedagogů k OER, zda své vzdělávací zdroje pod veřejnou licencí zveřejňují a na ostatní zdroje odkazují. A jaké je právní povědomí učitelů o autorském právu a zda o těchto aspektech studenty informují."

\section{Afiliace}

Výzkum byl podpořen Grantovou agenturou Univerzity Karlovy (projekt č. 970218 s názvem Využívání otevřených vzdělávacích zdrojů studenty environmentálních oborů v České republice), Univerzita Karlova, Fakulta humanitních studií, 2018.

\section{Poděkování}

Poděkování patří pedagogům, kteří dovolili organizovat výzkum mezi jejich studenty, stejně tak studentům, kteří byli ochotni vyplnit dotazníky. Za konzultace při př́pravě metodické části pak PhDr. Marii Pospíšilové a doc. PhDr. Richardu Papíkovi, Ph.D. Při statistickém vyhodnocení byl nápomocný Matej Marek, MSc. K celkovému zkvalitnění článku přispěly také připomínky recenzentů, za což jim děkuji. Značné poděkování patří RNDr. Janě Dlouhé, Ph.D. za její konzultace a redakční práci.

\section{Literatura $^{1}$}

- Acemoglu, D., Laibson, D., and List, J. A. (2014), "Equalizing superstars: The Internet and the democratization of education", American Economic Review, Vol. 104 No. 5, pp. 523-27.

- Allen, I. E., and Seaman, J. (2016), "Opening the curriculum: Open educational resources in US Higher Education, 2016", available at: http://www.onlinelearningsurvey.com/oer.html (accessed 30 January 2018).

1 Překlady v textu článku jsou dílem autora. 
- Bone, Elizabeth and McNichol, Sarah. (2014), Students' views on learning methods and Open Educational Resources in higher education, The Higher Education Academy, York.

- Butcher, N. (2010), "Open educational resources and higher education", available at: http://www.oerafrica.org/FTPFolder/resources/OER\%20in\%20HE\%20concept\%20paper.pdf (accessed 30 January 2018).

- Dlouhá, J., Petiška, E., Dlouhý, J., and Kapitulčinová, D. (2015), "Opportunities and Risks of the Use of Open Education Resources in Environmental Disciplines at University Level in the Czech Republic: A Criteria for Assessing Quality", Envigogika, Vol. 10 No. 4.

- Hewlett Foundation. (2018), "Open Educational Resources", available at: https://hewlett.org/strategy/open-educational-resources/ (accessed 12 November 2018).

- Hilton, J. (2016), "Open educational resources and college textbook choices: a review of research on efficacy and perceptions", Educational Technology Research and Development, Vol. 64 No. 4, pp. 573-590.

- Hilton III, J., Wiley, D., Stein, J., \& Johnson, A. (2010). The four 'R's of openness and ALMS analysis: frameworks for open educational resources. Open Learning, Vol. 25 No. 1, 37-44., available at: https://scholarsarchive.byu.edu/cgi/viewcontent. cgi?article $=1821 \&$ context $=$ facpub

- Hodgkinson-Williams, C., and Paskevicius, M. (2012), "The role of postgraduate students in co-authoring open educational resources to promote social inclusion: a case study at the University of Cape Town", Distance Education, Vol. 33 No. 2, pp. 253-269.

- Hu, E., Li, Y., Li, J., and Huang, W. H. (2015), "Open educational resources (OER) usage and barriers: a study from Zhejiang University, China", Educational Technology Research and Development, Vol. 63 No. 6, pp. 957-974., available at: https://link.springer.com/article/10.1007/s11423-015-9398-1 (accessed 12 November 2018).

- Hylén, J. (2006), "Open educational resources: Opportunities and challenges", available at: http://ubir.bolton.ac.uk/290/1/iec_reports-1.pdf (accessed 30 January 2018).

- ITU - International Telecommunication Union. (2015), "Advancing Sustainable Development through Information and Communication Technologies: WSIS Action Lines Enabling SDGs", available at: http://www.itu.int/net4/wsis/sdg/Content/wsissdg_booklet.pdf (accessed 30 January 2018).

- Kapitulčinová, D., a kol. (2015). Analýza využívání termínu Open Educational Resources na českých vysokých školách v mezinárodním kontextu. AULA, 2015, Vol. 23, No. 2: 29-48.

- Masterman, L., Wild, J., White, D., Wild, J., Masterman, L., and Manton, M. (2011), "JISC Open Educational Resources Programme: Phase 2 OER Impact study: Research report", available at: https://weblearn.ox.ac.uk/access/con- 
tent/group/ca5599e6-fd26-4203-b416-f1b96068d1cf/Research\%20Project\%20Reports/OER\%20Projects\%202011-2014/JISC\%200ER\%20Impact\%20Study\%20Research\%20Report\%20v1-0.pdf (accessed 30 January 2018).

- Onaifo, Daniel. (2016), "Alternate Academy: Investigating the Use of Open Educational Resources by Students at the University of Lagos in Nigeria", available at: http://ir.lib.uwo.ca/cgi/viewcontent.cgi?article=5467\&context=etd (accessed 30 January 2018).

- Petiška, E. (2018), "Usage of Open Educational Resources (OER) by Students of Environmental Disciplines in the Czech Republic", Envigogika, Vol. 13 No. 1., pp. 118. available at: https://www.envigogika.cuni.cz/index.php/Envigogika/article/view/548/770 (accessed 12 November 2018).

- Roeder, I., Severengiz, M., Stark, R., and Seliger, G. (2017), "Open educational resources as a driver for manufacturing-related education for learning of sustainable development", Procedia Manufacturing, Vol. 8, pp. 81-88.

- Shigeta, K., Koizumi, M., Sakai, H., Tsuji, Y., Inaba, R., and Hiraoka, N. (2017), "A survey of the awareness, offering, and adoption of OERs and MOOCs in Japan", Open Praxis, Vol. 9 No. 2, pp. 195-206.

- TES Global. (2016), "Three in Four U.S. Teachers Say Open Educational Resources Are Used More Often Than Textbooks", available at: https://oerknowledgecloud.org/content/three-four-us-teachers-say-open-educational-resources-areused-more-often-textbooks (accessed 14 November 2018).

- Wiley, D., Bliss, T. J., and McEwen, M. (2014), "Open Educational Resources: a review of the literature", in Handbook of research on educational communications and technology, Springer, New York, pp. 781-789. 


\section{Př́loha 1 dotazník ${ }^{2}$}

V dotazníku jsou pojmem otevřené vzdělávací zdroje (OER) myšleny všechny zdroje ke studiu, které jsou bezplatně dostupné na internetu pro všechny (např. Wikipedie, webové stránky atd.) a které Ti jakýmkoli způsobem pomáhají při Tvém studiu problematiky životního prostředí (ŽP) a to jak při plnění studijních požadavků, tak při studiu nad jejich rámec.

1) Jsem (zakroužkuj):

2) Studuji (zakroužkuj)

3) Uved' školu a katedru, na níž studuješ:

4) Ohodnot' všechny otevřené vzdělávací zdroje (OER) v tabulce následovně:

V prvním řádku Frekvence využívání ohodnot' jak často využíváš daný zdroj při studiu ŽP: 1=denně; 2=týdně; 3=měsíčně; 4=méně často; 5=nevyužil jsem, vím, že existuje; $6=n e-$ znám

Ve druhém řádku Hodnocení kvality ohodnot' jak Ti prǐide daný zdroj kvalitní ke studiu ŽP: 1=rozhodně kvalitní; 2=spiše kvalitní; 3=nevím; 4=spíše nekvalitní; 5=rozhodně nekvalitní

Ve třetím řádku uved' Účely využívání uved' všechny účely pro které zdroj využíváš při studiu ŽP:

1=hlavní zdroj; 2=doplněk a sekundární zdroj; 3=rozcestník k dalším zdrojům; 4=příprava na zkoušky/psaní atestačních prací; $5=$ =studium nad rámec studij. požadavků Pokud znáš další OER ke studiu ŽP, uved' je do prázdných míst (Název zdroje) a také ohodnot:

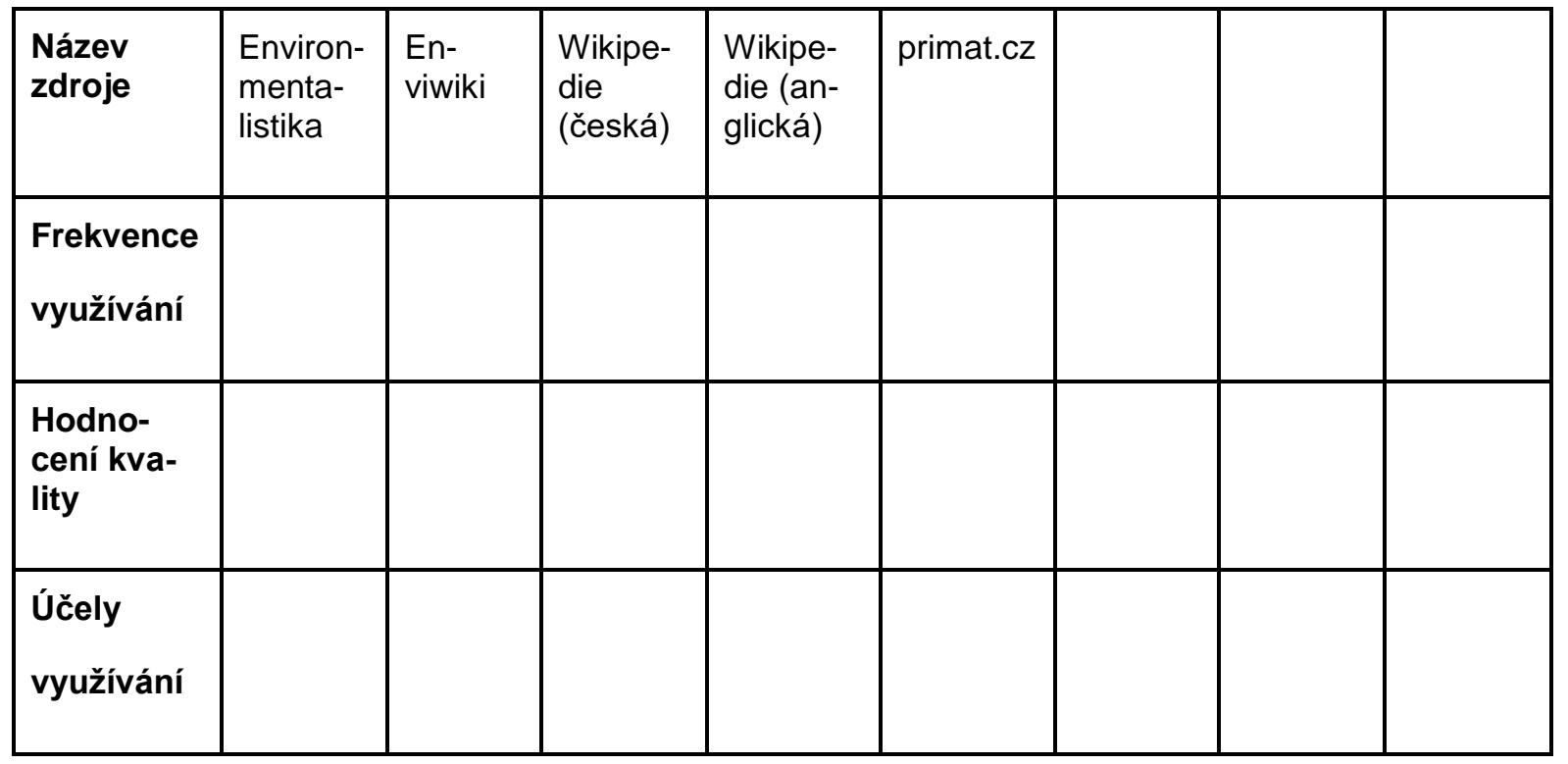

2 V rámci dotazníku studentům tykáme pro osobnější přístup k vyplňování. Na základě připomínky recenzenta ale uznáváme, že může být vhodnější používat formálnější přístup a respondentům vykat. 
5) Můžeš napsat $v$ bodech 3 hlavní kritéria, podle kterých posuzuješ kvalitu OER? Každé kritérium napiš na jeden řádek, pokud nevíš, nechej prázdný rádek.

1.

2.

3.

6) Ke studiu ŽP ze zdrojů OER nejčastěji využíváš (můžeš zakroužkovat více odpovědí):

1. Video 2 . Online zprávy a diskuze 3 . Specializované portály 4 . Weby s různým obsahem

5. e-knihy a výukové texty (např. digitalizovaná skripta) 6 . Odborné texty (např. vědecké články) 7. Úložiště materiálů / studentské weby 8 . Internetové encyklopedie 9.

Jiné

7) Využíváš OER při studiu ŽP více či méně než uzavřené zdroje (např. tištěná skripta)?

1. Více OER než uzavřené zdroje 2 . Přibližně stejně 3 . Uzavřené zdroje více než OER

8)Co na OER, jež používáš ke studiu ŽP, oceňuješ nejvíce?(můžeš zakroužkovat více odpovědí):

1. Dostupnost 2. Množství informací 3. Snadnou orientaci v jejich rámci (odkazy, hyperlink)

4. Přehlednou strukturu 5. Kvalitu informací 6 . Jiné

9) Jak se dozvídáš o OER s problematikou ŽP? (můžeš zakroužkovat více odpovědí):

1. Od studentů 2. Od pracovníků VŠ 3. Přes internetové vyhledávače 4. Jinak 